\title{
EFFECT OF SUPERVISOR'S ROLE IN TRAINING PROGRAMS AND MOTIVATION TO LEARN AS A PREDICTOR OF JOB PERFORMANCE
}

\author{
Azman Ismail \\ Faculty of Cognitive Sciences \& Human Development \\ Universiti Malaysia Sarawak. \\ Email:iazman@fcs.unimas.my \\ Larry M. Dooley \\ Educational Administration and Human Resource Development \\ College of Education and Human Development. \\ Texas A\&M University, US. \\ Email: l-dooley@tamu.edu \\ Sheela Chitra Chandra Segaran \\ Faculty of Cognitive Sciences \& Human Development. \\ Universiti Malaysia \\ Email: sheela.c@hlgroup.com.my
}

\begin{abstract}
Training research literature highlights that the ability of supervisors to play proper roles in training programs may directly increase job performance. More importantly, extant research in this field reveals that the effect of supervisor's role in training programs on job performance is indirectly affected by motivation to learn. The nature of this relationship is less emphasized in training management literature. Therefore, this study was conducted to measure the effect of supervisor's role in training programs and motivation to learn on job performance using 100 usable questionnaires gathered from technical employees who have worked in one city based local authority in Sarawak, Malaysia (MSCLAS). Outcomes of stepwise regression analysis showed that relationship between motivation to learn and supervisor role characteristics (i.e., support and communication) positively and significantly correlated with job performance. This result confirms that motivation to learn does act as a full mediating role in the training model of the studied organization. Implications of this study to training management theory and practice, methodological and conceptual limitations, as well as future directions are discussed.
\end{abstract}

Keywords: supervisor's role in training programs, motivation to learn, job performance

\section{INTRODUCTION}

Supervisors are the first level of management given major duties and responsibilities to lead work groups in organizations (Elangovan \& Karakowsky, 1999; Goldstein \& ford, 2002; Noe 2005). As an experienced leader, problem solver and role model at the group level, supervisors often work together with their employers to design, implement and monitor the organizational policies, procedures and plans, including training programs (Comstock, 1994; Ellinger et al., 2005; Robbins \& DeCenzo, 2004). The training program is a strategic 
function of human capital management, where it focuses on developing employee competencies to overcome daily problems. This may lead to supporting the development and growth of an organization in the future (DeSimone, Warner \& Harris, 2002; MacNeil, 2004). In the traditional management perspective, supervisors are given the important responsibility by an employer to identify daily, routine and short-term employee deficiencies, as well as report such deficiencies to top management. Top management will then identify the training requirements to overcome such employee deficiencies (Pfeffer, 1998; Rodrígues \& Gregory, 2005).

In an era of global competition, many organizations have shifted their paradigms from traditional job based training to organizational business strategies and cultures (ismail et al., 2007; Ellinger et al., 2005; MacNeil, 2004). Under this approach, supervisors are empowered by an employer to effectively design and administer training programs to develop useful competencies for future organizational development. In the design of training programs, supervisors often work together with the management team and employees in establishing objectives, selecting suitable trainers, developing lesson plans, selecting program methods and techniques, preparing materials, scheduling the program, as well as conducting training needs analyses (Goldstein \& Ford, 2002; Golemen, 2000; Nijman, 2004). In the administration of training programs, supervisors usually refer to the management team and experienced employees to ensure that the implementation of training activities will achieve the objectives (DeSimone et al., 2002; Elangovan \& Karakowsky, 1999; Yamnill \& McLean, 2001). For example, the role of supervisors in administering training programs does not only provide financial and physical facility supports, but they also have the capabilities to establish realistic learning expectations, encourage positive reinforcements, create a positive impetus for the training program, make employees feel comfortable to attend training, and improve and develop employees' competencies (Brinkerhoff \& Montesino, 1995; Golemen, 2000).

Supervisor role is a critical organizational context that may support or resist empoyees to enter and participate in training programs (Blanchard \& Thackers, 2007; Noe, 1986, 2005). Many scholars identify that support and communication are two salient supervisor role characteristics that affect effectiveness of training programs (Ismail et al., 2007; Chiaburu \& Tekleab, 2005; Facteau et al., 1995). Supervisor support is often related to a supervisor who provides encouragement and opportunities to employees to improve their performance in organizations (MacNeil, 2004; Noe, 2005). In a training context, supervisors often encourages trainees to attend training programs, helps employees before, during and after training programs in terms of time, budgetary support and resources, involves employees in decision-making, and guides trainees in applying competencies that they learned in the workplace (Elangovan \& Karakowsky, 1999; Nijman, 2004; Tai, 2006). While, supervisor communication is often viewed as the activity or process of expressing ideas or feelings while giving people information, as well as exchanging ideas and information between a person or a group through symbols, actions, written or spoken words in order to impart information and ideas effectively (Harris et al., 2000; Lumsden \& Lumsden, 1993). In a training program, supervisors openly delivering information about the procedures, content, tasks and objectives of the training program, conducting discussion about tasks that should be learned, giving detailed explanations about the benefits of attending training programs and providing performance feed- 
back (Harris et. al., 2000; Sisson, 2001). Extant research in this area highlights that the ability of supervisors to provide sufficient support and use good communication styles in training programs may lead to higher job performance (Baldwin \& Magjuka, 1991; McGraw, 1993). Job performance is generally seen as individual employees accomplishing their respective work goals, meeting their expectations, achieving job targets and/or accomplishing a benchmark set by their organizations (Bohlander et al., 2001; Eysenck, 1998; Maathis \& Jackson, 2000).

Interestingly, a careful investigation of such relationships reveals that effect of supervisor's role in training programs on job performance is indirectly influenced by motivation to learn (Cohen \& Leventhal, 1990; Farr \& Middlebrooks, 1990; Tracey et al., 2001). Several scholars, such as Blanchard and Thacker (2007), Knowles, (1984, 1989), and Noe (1986) state that motivation to learn consists of two major components: motivation and learn. Motivation is often defined as direction, persistence and amount of effort that may be expanded by an individual to achieve his/her particular objective. Learn is usually viewed from human cognitive and behavior perspectives. For example, cognitive theorists define learn as a relatively permanent change in cognition occurring as a result of experience. While, behavior theorists define learn as "a relatively permanent change in behavior in response to a particular stimulus or set of stimuli" (Noe, 1986: 736-170). Relying on cognitive and behavior perspectives, motivation to learn may be defined as intensity, persistence and direction of learning new knowledge, skills and attitudes affected by an individual who has clear goals, put high value of outcomes, high self-efficacy and satisfied with supervisors' treatments (Adams, 1963, 1965; Locke \& Latham, 1990; Vroom, 1964, 1973; Wood \& Bandura,
1989). If an individual has high enough of motivation to learn, this will increase his/her ability to overcome discouraging learning factors. Consequently, it may motivate an individual to follow, involve and commit to learning activities in order to improve work attitudes and behaviors, especially job performance (Axtell et al., 1997; Guerrero \& Sire, 2001; Nijman, 2004).

Within a training program perspective, the ability of supervisors to provide sufficient supports (e.g. encouragement and guidance) and use communication openness in training management (e.g. feedback and discussion) will invoke their employees' motivation to learn, which in turn lead to higher job performance (Blanchard \& Thacker, 2007; Martocchio \& Webster, 1992; Tsai \& Tai, 2003). Although the nature of this relationship is interesting, little is known about the mediating role of motivation to learn in training management literature (Chiaburu \& Takleab, 2005; Tai, 2006; Tracey et al., 2001). Hence, it motivates the researchers to measure the effect of supervisor role in training programs and motivation to learn on job performance that occurs in one city-based local authority in Sarawak, Malaysia (MSCLAS). For confidential reasons, the name of actual organization is kept anonymous.

\section{LITERATURE REVIEW \\ Context of the Study}

Many researchers argue that sociocultural differentiations are among the important factors that affect training program management in organizations (Desimone $e t$ al., 2002; Goldstein \& Ford, 2002). For example, one dimension of culture that can have implications for attitudes to training programs is the concept of collectivism and individualism. Collectivism is perceived as the norm and standard that practices large power distance (e.g., more hierarchical structure and centralized decision making) 
and emphasizes more on group interests, cooperation, loyalty and harmony. Individualism is a term used to describe the value and standard that practice low power distance (e.g., less hierarchy and decentralized decision making) and focus more on individual achievement (Hofstede, 1991; Redding \& Wong, 1993). The literature suggests that Malaysians tends to reflect collectivism culture. The influence of collectivism culture in Malaysian public sector can be traced in the website of the Public Service Department (PSD). For example, the government of Malaysia has established a National Institute of Public Administration (INTAN) as a human capital development center to design and implement the various types of training programs for government departments in this country, as well as conduct certain international courses. Participants that attend the training programs are from the top, middle and low management levels who work in the federal government agencies, state government agencies and local authorities. The primary objective of a training program is to prepare public administration to support the changes of national development, vision, mission and goals (Mat, 1988; Siew Nooi, 1988; INTAN, 2007). In order to improve the customer's needs at the grass roots level, INTAN first established a Center for Urban and Environmental Management in September 2000. This center was restructured to become the Local Government and District Management in January 2004. Its main function is to improve the capacity and capability of local authorities in providing services and managing resources, formulate positive changes in developing and managing local government and to meet the customer's needs (INTAN, 2007).

The nature of Malaysian public sector has affected the administration of training programs in Malaysian local government. It consists of three types of local authorities: city hall, municipality council and district council. These authorities are responsible to the Ministry of Local Government and Housing. These authorities rely very much on traditional incomes from the taxes besides federal government funding to sponsor rural and urban development projects (Jabatan Kerajaan Tempatan Malaysia, 2007). Due to many commitments, these authorities do not have sufficient budget for training programs. This situation encourages management to send their staff (e.g., supervisor) to management and skills based training programs offered by professional training providers and/or INTAN. Upon returning from such training programs, they are required to conduct formal and/or informal training (e.g., coaching and mentoring) for their own staff. This approach is often practiced to create a positive learning culture and to enhance competencies among staff. Specifically, in MSCLAS, all technical employees are entitled to attend training programs sponsored by the organization. In managing training programs, supervisors have provided technical supports (e.g., budgetary, materials, facilities) and non-technical supports (e.g., encouragement, and practicing good interaction) to motivate technical employees' learning and applying new competencies in the workplace. A thorough investigation of the in-depth interview results showed that the motivation to learn has indirectly influenced the effect of the supervisor's role on job performance in the organization. For example, the ability of supervisors to provide material and moral supports as well as to practice good interpersonal communication (e.g., provide constructive feedback and open discussion) have increased employees' motivation to learn, which in turn, lead to increased job performance in the workplace. However the nature of such relationships is interesting, little is known about the mediating role of motivation to learn because of the paucity of training research literature in this country (Ismail et al., 2007). 
Relationship between Supervisor's Role, Motivation to Learn and Job Performance

The influence of motivation to learn in the training programs of the studied organization is consistent with training program literature mostly published in Western countries. For example, Axtell et al. (1997) used a direct effects model to examine the training transfer based on a sample of 45 trainees in UK organizations. They found that motivation to learn acquired knowledge and skills had increased longer performance in the workplace. Further investigation of studies about supervisor's role in several US organizations show that supervisors sufficiently provide supports (i.e., material and moral) to employees before, during and after attending training program (Chiaburu \& Tekleab, 2005; Gupta \& Govindarajan, 2000), and supervisors properly practice good communication styles (i.e., constructive feedback and communication openness) while explaining the purposes, significance, and valued outcomes before, during and after attending training programs (Brown et al., 2001; Brinkerhoff et al., 1995) had been important determinants of employees' motivation to learn up to date knowledge, new skills and good moral values. As a result, it could lead to greater job performance in the organizations (Brown et al., 2001; Brinkerhoff et al., 1995; Chiaburu \& Tekleab, 2005; Gupta \& Govindarajan, 2000). Specifically, Tai (2006) conducted a study about training programs based on a sample of 126 employees in Northern Taiwan. This study found that the willingness of supervisors to provide well-design training frames and better explanations about the training plans had invoked employees' motivation to learn up to date knowledge, new skills and positive attitudes in the training programs. As a result, it could lead to increased training effectiveness, such as job performance.
These studies are consistent with the notion of motivation to learn theories. For example, Locke and Latham's (1990) goal setting postulates that goals direct individuals to perform a task. Application of this theory in training management shows that the ability of a supervisor to design training objectives that meet employees' needs and provide clear explanations about the procedures of attaining the goals will strongly increase employees' motivation to learn. As a result, it may lead to increased job performance (Goldstein \& Ford, 2002; Mathieau et al., 1992). Wood and Bandura's (1989) social learning theory reveals that self-efficacy reinforces individuals' performance. Application of this theory in training programs shows that the ability of a supervisor to encourage employees learning a proper technique and providing clear explanations about the procedures of attaining the goals will strongly increase employees' motivation to learn. As a result, it may lead to increased job performance (Brown et al., 2001; Goldstein \& Ford, 2002).

Adams' (1963 \& 1965) equity theory states that unfair or fair treatment has a significant impact on individual attitudes and behaviors. Application of this theory in training management shows that employees who receive sufficient supports from their supervisors while applying and attending training programs will perceive equity. If individuals feel that they are fairly treated by their supervisors, this will invoke motivation to learn, which in turn, lead to an increased job performance (Chiaburu \& Takleab, 2005; Mathieu et al., 1992). Vrooms' (1964 \& 1973) expectancy theory highlights that an individual will perform certain actions if he/she perceives such actions may bring valued outcomes. Application of this theory in training management shows that the ability of a supervisor to openly and honestly communicate the value of attending training programs and its importance of 
learning new competencies will strongly increase employees' motivation to learn. As a result, it may lead to increased job performance (Cohen \& Leventhal, 1990; Farr \& Middlebrooks, 1990).

The literature has been used as foundation to develop a conceptual framework for this study as shown in Figure 1. Based on the framework, it seems reasonable to assume that the ability of a supervisor to play proper roles in training programs will affect MSCLAS employees' motivation to learn and that may increase their performance as this motivation does affect Western employees. Therefore, it can be hypothesized that:

H1: Motivation to learn positively mediates the effect of supervisor support on job performance

H2: Motivation to learn positively mediates the effect of supervisor communication on job Performance

Independent Variable Mediating Variable Dependent Variable

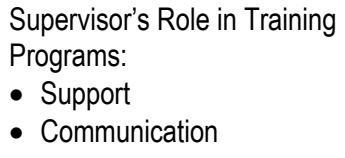

Figure 1: Motivation to Learn Mediates the Relationship between Supervisor's Role in Training Programs and Job Performance 


\section{RESEARCH METHODOLOGY}

This study used a cross-sectional research design that allowed the researchers to integrate training management literature, the in-depth interview, the pilot study and the actual survey as a main procedure to gather data. The use of such methods may gather accurate and less biased data (Cresswell, 1998; Sekaran, 2000). At the initial stage of this study, in-depth interviews were conducted involving six experienced employees, namely an experienced technician, an assistant Human Resource Manager, a Head of the Training Unit, a supervisor and two senior officers of the Technical Department. They are selected based on purposive sampling where the employees have good knowledge and experiences in the design and administration of training programs. Information gathered from such employees helped the researchers to understand the nature of supervisor's role, employee motivations and employee performances practiced in the studied organization. After refining, categorizing and comparing the information with relevant theoretical and empirical evidence, this was used as a guideline to develop the content of the survey questionnaires for a pilot study. Next, a pilot study was initiated by discussing the survey questionnaires with the above participants in order to verify the content and format of survey questionnaires for the actual study. The back translation technique was used to translate the survey questionnaires in Malay and English; this may increase the validity and reliability of the instrument (Van Maanen, 1983; Wright, 1996).

The survey questionnaire consisted of 4 sections. Firstly, supervisor support was measured using 4 items and it was modified from training research literature (Chiaburu \& Takleab, 2005; Tai, 2006; Tsai \& Tai, 2003). Secondly, supervisor communication was measured using 4 items that were modi- fied from transfer of training literature (Foxon, 1993; Xiao, 1996; Yamnill \& McLean, 2001). Thirdly, motivation to learn was measured using 5 items and it was modified from the training program literature (Foxon, 1993; Noe, 2005; Rodríguez \& Gregory, 2005; Tsai \& Tai, 2003). Finally, job performance was measured using 5 items that were modified from job performance literature (Hvang et al., 2004; Lawler \& Hall, 1970). All items used in the questionnaires were measured using a 7 -item scale ranging from "strongly disagree" (1) to "strongly agree" (7). Demographic variables were used as a controlling variable because this study also focused on employees' attitudes.

The targeted population of this study was 195 technical employees of the MSCLAS. A convenience sampling technique was used to distribute 150 questionnaires to technical employees through contact persons (e.g., secretary of department heads, assistant HR managers, supervisors and/or HR managers). Of the number, 100 usable questionnaires were returned to the researchers, yielding a response rate of 67 percent. The survey questionnaires were answered by participants based on their consents and voluntary basis. The Statistical Package for Social Science (SPSS) version 16.0 was used to analyse the psychometric properties of questionnaire data and thus testing the research hypothesis.

\section{RESEARCH FINDINGS}

Table 1 shows the participant characteristics in MSCLAS. The majority respondent characteristics were male (92 percent), age between 30 to 39 years old (47 percent), technicians who held Malaysian Certificate of Education (45 percent), technicians who worked less than 5 years (33 percent) and group leader and supervisor positions (39 percent).

Table 1: Respondent Characteristics $(\mathrm{N}=100)$ 


\begin{tabular}{|c|c|c|c|c|c|c|c|}
\hline Gender (\%) & Age (\%) & \multicolumn{2}{|c|}{ Education (\%) } & \multicolumn{2}{|c|}{$\begin{array}{l}\text { Length of Service } \\
(\%)\end{array}$} & \multicolumn{2}{|l|}{ Position (\%) } \\
\hline Male $=92$ & $20-29=27$ & Degree & $=9$ & $1-5$ years & $=33$ & Engineer/Planner & $=7$ \\
\hline Female $=8$ & $30-39=47$ & Diploma/STPM & $=20$ & $6-10$ years & $=20$ & Group Leader/Supervisor & $=39$ \\
\hline & $40-49=22$ & MCE/SPM & $=45$ & $11-15$ years & $=20$ & Technician & $=21$ \\
\hline & $>49=4$ & LCE /SRP/PMR & $=12$ & $16-20$ years & $=25$ & Landscape /maintenance & $=3$ \\
\hline & & Others & $=14$ & $>20$ years & $=2$ & $\begin{array}{l}\text { Architect } \\
\text { Others }\end{array}$ & $\begin{array}{l}=7 \\
=23\end{array}$ \\
\hline
\end{tabular}

Note:

SRP/LCE/PMR: Sijil Rendah Pelajaran/Lower Certificate of Education/Penilaian Menengah Rendah

SPM/MCE : Sijil Pelajaran Malaysia/ Malaysia Certificate of Education

STPM : Sijil Tinggi Pelajaran Malaysia

Table 2 and Table 3 show the results of psychometric assessment for measurement scales. The original survey questionnaires consisted of 18 items, which related to four variables: support (4 items), communication (4 items), motivation to learn (5 items) and job performance (5 items). The factor analysis with direct oblimin rotation was first done for all variables. Further, the Kaiser-Mayer-Olkin Test (KMO) which is a measure of sampling adequacy was conducted for each variable and the results indicated that it was acceptable. Specifically, these statistical results showed that (1) all research variables exceeded the acceptable standard of Kaiser-MeyerOlkin's value of 0.6 , (2) all research variables were significant in Bartlett's test of sphericity, (3) all research variables had eigenvalues larger than 1, and (4) the items for each research variable exceeded factor loadings of 0.50 (Hair et al., 1998). Besides that, all research variables exceeded the acceptable standard of reliability analysis of 0.70 (Nunally \& Bernstein, 1994). These statistical analyses confirm that the measurement scales met the acceptable standard of validity and reliability analyses as shown in Table 2 and Table 3. 
Table 2: Item Validity

\begin{tabular}{|c|c|c|c|c|c|}
\hline & \multirow{2}{*}{ Item } & \multicolumn{4}{|c|}{ Component } \\
\hline & & 1 & 2 & 3 & 4 \\
\hline \multirow[t]{4}{*}{ Support } & Care about my needs to have knowledge and skills & & .92 & & \\
\hline & $\begin{array}{l}\text { Motivate me due to my good performance after attending } \\
\text { training }\end{array}$ & & .86 & & \\
\hline & Always give constructive criticism & & .88 & & \\
\hline & $\begin{array}{l}\text { Assist me to apply the knowledge and skills learned from } \\
\text { the training }\end{array}$ & & .83 & & \\
\hline \multirow[t]{4}{*}{ Communication } & $\begin{array}{l}\text { Clearly explains the objective of attending training pro- } \\
\text { gram }\end{array}$ & & & & .83 \\
\hline & $\begin{array}{l}\text { Give information regarding the training program (Example: } \\
\text { changes on date and venue) }\end{array}$ & & & & .63 \\
\hline & Praise me when I do my job well & & & & .62 \\
\hline & $\begin{array}{l}\text { Listens to my opinion regarding the needs of training } \\
\text { program }\end{array}$ & & & & .57 \\
\hline \multirow[t]{5}{*}{ Motivation to Learn } & Interest to learn new knowledge and skills in training & & & .84 & \\
\hline & $\begin{array}{l}\text { Interest to attend training programs that is related to area } \\
\text { of work. }\end{array}$ & & & .86 & \\
\hline & $\begin{array}{l}\text { Give full attention regarding the content of the training } \\
\text { program. }\end{array}$ & & & .83 & \\
\hline & Prepare to give full concentration during training & & & .84 & \\
\hline & $\begin{array}{l}\text { Prepare to accept any task given by the manager or su- } \\
\text { pervisor }\end{array}$ & & & .85 & \\
\hline \multirow[t]{5}{*}{ Job Performance } & Give full attention while performing my job & .90 & & & \\
\hline & $\begin{array}{l}\text { Never give up even though the task is very difficult to be } \\
\text { done }\end{array}$ & .86 & & & \\
\hline & Take my job as a challenge & .90 & & & \\
\hline & $\begin{array}{l}\text { Willing to put in a sense of effort beyond that normally } \\
\text { expected when performing job }\end{array}$ & .85 & & & \\
\hline & $\begin{array}{l}\text { Feel a great sense of personal } \\
\text { satisfaction when I do my job well }\end{array}$ & .87 & & & \\
\hline
\end{tabular}

Table 3: The Result of Validity and Reliability Analyses

\begin{tabular}{lccccccc}
\hline \multicolumn{1}{c}{ Measure } & Items & $\begin{array}{c}\text { Factor } \\
\text { Loadings }\end{array}$ & KMO & $\begin{array}{c}\text { Bartlett's Test of } \\
\text { Sphericity }\end{array}$ & $\begin{array}{c}\text { Eigenval- } \\
\text { ue }\end{array}$ & $\begin{array}{c}\text { Variance } \\
\text { Explained }\end{array}$ & $\begin{array}{c}\text { Cronbach } \\
\text { Alpha }\end{array}$ \\
\hline $\begin{array}{l}\text { Support } \\
\text { Communication }\end{array}$ & 4 & 0.83 to 0.92 & 0.84 & $309.56, p=.000$ & 3.29 & 82.17 & 0.93 \\
Motivation to & 5 & 0.57 to 0.83 & 0.66 & $214.74, p=.000$ & 2.82 & 70.54 & 0.86 \\
$\begin{array}{l}\text { learn } \\
\text { Job Perfor- }\end{array}$ & 5 & 0.83 to 0.87 & 0.88 & $416.44, p=.000$ & 3.97 & 79.39 & 0.93 \\
mance & & 0.85 to 0.90 & 0.87 & $432.33, p=.000$ & 4.02 & 80.37 & 0.94 \\
\hline
\end{tabular}

Table 4: Pearson Correlation Analysis and Descriptive Statistics

\begin{tabular}{|c|c|c|c|c|c|c|}
\hline \multirow{2}{*}{ Variable } & \multirow{2}{*}{ Mean } & \multirow{2}{*}{$\begin{array}{l}\text { Standard } \\
\text { Deviation }\end{array}$} & \multicolumn{4}{|c|}{ Pearson Correlation Analysis } \\
\hline & & & 1 & 2 & 3 & 4 \\
\hline Support & 5.6 & 0.9 & (1) & & & \\
\hline Communication & 5.5 & 0.8 & $.73^{* *}$ & (1) & & \\
\hline Motivation to Learn & 6.1 & 0.7 & $.25^{*}$ & $.43^{* *}$ & (1) & \\
\hline Job Performance & 6.2 & 0.7 & .09 & $.35^{* *}$ & $.66^{* *}$ & (1) \\
\hline
\end{tabular}

Note: Significance at $* 0.05 ; * * 0.01 \quad$ Reliability Estimation was shown in a diagonal (1) 
Table 4 showed the results of Pearson correlation analysis and descriptive statistics. The mean values for the variables are from 5.5 to 6.2 , signifying that the levels of supervisor's support, supervisor communication, motivation to learn and job performance ranging from high (4) to highest level (7). Supervisor support positively and insignificantly correlated with job performance $(r=0.09, p>0.01)$ and supervisor communication positively and significantly correlated with job performance $(r=0.35, p<0.01)$, indicating that supervisor communication is an important antecedent of job performance. The correlation coefficients for the relationship between the independent variable (supervisor communication) and the mediating variable (motivation to learn) and the dependent variable (job performance) were less than 0.90 , indicating that the data were not affected by serious co linearity problem (Hair, et al., 1998).

Stepwise regression analysis was undertaken to test the mediating hypothesis because it can assess the magnitude of each independent variable, and vary the mediating variable in the relationship between many independent variables and one dependent variable (Baron \& Kenny, 1986; Foster et al., 1998). According to Baron and Kenny (1986), the mediating variable can be considered when it meets three conditions: first, the predictor variables are significantly correlated with the hypothesized mediator. Second, the predictor and mediator variables are all significantly correlated with the dependent variable. Third, a previously significant effect of predictor variables is reduced to non-significance or reduced in terms of effect size after the inclusion of mediator variables into the analysis (Wong et al., 1995). In this regression analysis, standardized coefficients (standardized beta) were used for all analyses (Jaccard et al., 1990). The results of testing research hypotheses using a stepwise regression analysis were shown in Table 4.

Table 5 shows the results of testing research hypothesis in Step 3. The relationship between supervisor role characteristics (i.e., support and communication) and motivation to learn positively and significantly correlated with job performance $(B=.62$, $\mathrm{p}<0.000$ ), therefore $\mathrm{H} 1$ and $\mathrm{H} 2$ were fully supported. This relationship explains that before the inclusion of motivation to learn in Step 2, supervisor support and supervisor communication were significantly correlated with job performance $(\beta=.58, \mathrm{p}<0.000 ; \beta=-$ $.32, \mathrm{p}<0.05$, respectively). In terms of explanatory power, the exclusion of motivation to learn in this Step 2 had explained 21 percent of the variance in dependent variable. As shown in step 3, (after the inclusion of motivation to learn into this step), the previous significant relationship between supervisor's role (i.e., support and communication) did not change to non-significant ( $\beta=-.24$, $\mathrm{p}<0.05 ; \beta=.25, \mathrm{p}<0.05$, respectively), but the strength of such relationships were decreased. In terms of explanatory power, the inclusion of motivation to learn in Step 3 had explained 50 percent of the variance in dependent variable. This result demonstrates that motivation to learn does act as a full mediating variable in the training management model of the organizational sample. 
Table 5: Result for Stepwise Regression Analysis

\begin{tabular}{lccc}
\hline \multicolumn{1}{c}{ Variable } & \multicolumn{3}{c}{$\begin{array}{c}\text { Dependent Variable } \\
\text { (Job Performance) }\end{array}$} \\
\cline { 2 - 4 } & Step 1 & Step 2 & Step 3 \\
\hline Controlled Variable & .08 & .08 & .04 \\
Gender & -.01 & -.004 & -.001 \\
Age & -.09 & -.10 & -.09 \\
Education & .06 & .02 & .04 \\
Length of Service & .09 & .12 & -.001 \\
Type of Training & -.11 & -.10 & -.14 \\
Type of Learning & -.01 & -.01 & .04 \\
Position & & & $-.24^{*}$ \\
Independent Variable & & $-.32^{*}$ & $.25^{*}$ \\
Supervisor Support & & $.58^{* * *}$ & \\
Supervisor Communication & & & $.62^{* * *}$ \\
Mediating Variable & & .21 & .50 \\
Motivation to Learn & & .13 & .44 \\
R Square & .04 & .17 & .29 \\
Adjusted R Square & .03 & $2.62^{* *}$ & $8.73^{* * \star}$ \\
R Square Change & .04 & $9.42^{* * *}$ & $50.67^{* * *}$ \\
F & .57 & & \\
F $\Delta$ R Square & .57 & &
\end{tabular}

Note: Significance at $* \mathrm{p}<0.05 ; * * \mathrm{p}<0.01 ; * * * \mathrm{p}<0.001$

\section{DISCUSSION AND IMPLICATIONS}

The findings of this study confirm that motivation to learn does act as a full mediating variable in the relationship between supervisor's role and job performance in the organizational sample. In the context of MSCLAS, supervisors have provided adequate supports (e.g., encourage employees to attend training programs and apply newly knowledge and skills that they gain from training programs) and used good communication practices (e.g., provide feedback, encourage discussion and openly deliver information on training) when dealing with training programs. The majority of the employees perceive that such supervisors' role had increased their motivation to learn. When employees' motivation to learn have increased this may lead to higher job performance in the organization.

This study provides significant impacts on three major aspects: theoretical contribution, robustness of research methodology, and contribution to the Human Resource Practitioners. In terms of theoretical contribution, this study revealed two important outcomes. Firstly, motivation to learn does act as a mediating variable in the relationship between supervisor support and job performance. This finding is consistent with the studies by Chiaburu and Takleab (2005), and Gupta and Govindarajan (2000). Secondly, motivation to learn does act as a mediating variable in the relationship between supervisor communication and job performance. This result is consistent with the studies by Brown et al. (2001), and Brinkerhoff et al (1995). In sum, the findings of this study have supported and broadened training research literature published in most Western countries. Thus, the notion of motivation to learn has been successfully applied within the training management models of the studied organization. With 
respect to the robustness of research methodology, the data gathered using training management literature, the in-depth interviews, pilot study and survey questionnaires have exceeded an acceptable standard of validity and reliability analysis, thus leading to the production of accurate findings.

Regarding practical contributions, the findings of this study can be used as a guideline by HR managers to upgrade the efficiency and effectiveness of training programs in organizations. This objective may be achieved if they consider these suggestions: firstly, sharpen the capabilities of supervisors through updated training contents and methods. For example, the content of training programs for HR managers should emphasize knowledge and skills in training needs analysis, as well as understanding individuals from cognitive, emotion and psychomotor approaches. Hence, sufficient time for practical trainings well guided by professional trainers should be allocated to enable HR managers to learn the proper interpersonal communication, managing change, conflict and problem solving techniques. This training approach will be effective if it is organized consistently using modular methods. Secondly, allow supervisors to be involve in higher level training committees so that they may clarify the needs and expectations of employees at the grass root level; this may help to establish appropriate training modules that can support organizational and human resource management's strategies and goals. Thirdly, change human resource policies from hiring employees based on conforming to organization policies and procedures to hiring employees based on creative and innovation. For example, employees who have higher levels of creativity and innovation are able to use their knowledge, experiences and competencies to train operational employees in terms of attitudes and working styles, as well as to handle employees' demands with good treatments (e.g., show respect, honest and accountable). Finally, review compensation and benefits system for supervisors to base it on the current organizational strategy and goals. For example, internal organizational changes will increase duties and responsibilities of supervisors, this may affect health, safety and stress at the workplace. These problems may be decreased if the type, level and/or amount of rewards (e.g., pay rate and pay rise) are increased according to supervisors' workloads and performance. If organizations heavily consider these suggestions, this may increase supervisors' motivation to support organizational and departmental training's strategies and goals.

\section{CONCLUSION}

The findings of this study confirm that motivation to learn acts as a full mediating variable in the relationship between a supervisor's role and job performance. This result has supported and extended training research literature published in Western countries. Therefore, current research and practice within training management models needs to consider motivation to learn as a crucial aspect of the organizational training system where increasing individuals' motivation to learn may strongly induce subsequent positive personal outcomes (e.g., satisfaction, commitment, trust, good working ethics and performance). Hence, these positive outcomes may direct employees to sustain and achieve organisational competitiveness in a global economy. 


\section{REFERENCES}

Adams, J.S. (1963). "Towards an Understanding of Inequity”, Journal of Abnormal and Social Psychology, 67, 422-436.

Adams, J.S. (1965). "Inequity in Social Exchange. In L. Berkowitz (Eds.)", Advances in Experimental Social Psychology, 2, 267-299.

Axtell, C.M., Maitlis, S. (1997). Predicting Immediate and Longer-Term Transfer of Ttraining, Personnel Review, 26 (2), 201-13.

Baldwin, T.T., Ford, J.K. (1998). "Transfer of Training: A Review and Directions for Future Research”, Personnel Psychology, 41, 63-100.

Baron, R.M., Kenny, D.A. (1986). "This Moderator-Mediator Variable Distinction in Social Psychological Research: Conceptual, Strategic, and Statistical Considerations", Journal of Personality and Social Psychology, 51 (6), 1173-1182.

Bohlander, G., Snell, S., and Sherman, A. (2001). Managing Human Resources, SouthWestern College Publishing, Australia.

Blanchard, P.N., Thacker, J.W. (2007). Effective Training: Systems, Strategies, and Practices, Pearson Prentice-Hall, US.

Brinkerhoff, R.O., Montesino, M.U. (1995). "Partnerships for Training Transfer: Lessons From a Corporate Study". Human Resource Development Quarterly, 6 (3), 263-274.

Brown, S.P., Ganesan, S., and Challagala, G. (2001). "Self-Efficacy as a Moderator of Information-Seeking Effectiveness", Journal of Applied Psychology, 86, 1043-51.

Chiaburu, D.S., Tekleab, A.G. (2005). "Individual and Contextual Influences on Multiple Dimension of Training Effectiveness". Journal of European Industrial Training, 29 (8), 604-626.

Cohen, W., Leventhal, D. (1990). “Absorptive Capacity: A New Perspective on Learning and Innovation", Administrative Sciences and quarterly, 35, 128-52.

Comstock, T.W. (1994). Fundamental of Supervision: The First-Line Manager at Work, Delmar Publisher, New York.

Cresswell, J.W. (1998). Qualitative Inquiry and Research Design: Choosing among Five Traditions, SAGE publications, London.

DeSimone, R.L., Werner, J.M. \& Harris, D.M. (2002). Human resource development, Thomson Learning, Inc.

Elangovan, A.R., Karakowsky, L. (1999). "The Role of Trainee and Environmental Factors in Transfer of Training: An Exploratory Framework", Leadership and Organization Development Journal, 20, 268-275.

Ellinger, A.E., Ellinger, A.D., and Keller, S.B. (2005). "Supervisory Coaching in a Logistics Context, International", Journal of Physical Distribution \& Logistics Management, 35 (9), 620-636. 
Eysenck, M. (1998). Psychology: An Integrated Approach. New York: Addison-Wesley Longman Ltd.

Facteau, J.D., Dobbins, G.H., Russell, J.E.A., Ladd, R.T., \& Kudisch, J.D. (1995). “The Influence of General Perceptions of the Training Environment on Pretraining Motivation and Perceived Training Transfer". Journal of Management, 21(1), 1-25.

Farr, J.L., Middlebrooks, C.L. (1990). Enhancing Motivation to Participate in Professional Development. In S.L. Willis, \& S.S. Dubin (Eds.), Maintaining Professional Competence, 195-213. San Francisco, Jossey-Bass, CA.

Foster, D.P, Stine, B., and Waterman, R. (1998). Business Analysis Using Regression: A Casebook, Springer-Verlag.

Foxon, M. (1993). "A Process Approach to the Transfer of Training. Part 1: The Impact of Motivation and Supervisor Support on Transfer Maintenance", Australian Journal of Educational Technology, 9 (2), 130-143.

Goldstein, I.L. \& Ford, J.K. (2002). Training in Organization: Needs Assessment, Development and Evaluation, Wadsworth Group, Thomson Learning, Inc., CA.

Golemen, D. (2000). "Leadership that Gets Results”, Harvard Business Review, 78 (2), 7890 .

Hair, J.F., Anderson, R.E., Tatham, R.L., and Black, W.C. (1998). Multivariate Data Analysis, Prentice Hall International, Inc., New Jersey.

Guerrero, S., Sire, S. (2001). "Motivation to Train From the Workers' Perspective: Example of French companies", International Journal of Human Resource Management, 12 (6), 988-1004.

Gupta, A., Govindarajan, V. (2000). "Knowledge Flows within MNCs", Strategic Management Journal, 21, 473-96.

Harris, R., Simon, M., and Bone, J. (2000). More than Meets the Eye? Rethinking the Role of Workplace Trainer, Australian National Training Authority, 1-65.

Hofstede, G. (1991). Cultures and Organizations: Software of the Mind. McGraw-Hill, NY.

Hornby, A.S. (2000), Oxford Advance Learner's Dictionary, Oxford University Press, NY.

Hvang, I.C., Hvang, P.W., and Chen, Y.J. (2004). "A study of Taiwan's Travel Agent Salary: An Agency Theory Perspective", Tourism Management, 483-490.

INTAN. (2007). Programme: PKTD; Accessed June 7, 2007:http://www.intanbk.intan.my/cda/m_abot/abt_centres_detail.php?centre=pktd.

Ismail, A., Cheekiong, T, and Guatleng, O. (2007). The mediating role of motivation to learn in the relationship between supervisor's role and job performance, the Sixth Asian Conference of the Academy of HRD, Nov 2-6, 2007, Beijing, China.

Jabatan Kerajaan Tempatan Malaysia. (2007). Laman Web Rasmi-Jabatan Kerajaan Tempatan; Accessed June 7, 2007: http://www.kpkt.gov.my/jkt/malay/pro_fungsi_bah.asp 
Jaccard, J., Turrisi, R., and Wan, C.K. (1990). Interaction Effects in Multiple Regression, SAGE Publications, Inc.

Lawler, E.E., Hall, D.T. (1970). Relationship of Job Characteristics to Job Involvement, Satisfaction and Intrinsic Motivation, Journal of Applied Psychology, 54, 305-312.

Locke, E.A., Latham, G.P. (1990). A Theory of Goal Setting and Task Performance, Englewood Cliffs, Prentice Hall, NJ.

Lumsden, G., Lumsden, D. (1993). Communicating in Groups and Teams: Sharing Leadership, Wadsworth, Inc., CA.

Maathis, R.L., Jackson, J.H. (2000). Human Resource Management, South-Western College Publishing, Australia.

MacNeil, M.C. (2004). "Exploring the Supervisor Role as a Facilitator of Knowledge Sharing in Teams", Journal of European Industrial Training, 28 (1), 93-102.

Martocchio, J.J., Webster, J. (1992). "Effects of Feedback and Cognitive Playfulness on Performance in Microcomputer Software Training”, Personnel Psychology, 45, 553578 .

Mat, J. (1988). "Pendapat Pengarah INTAN", Buletin INTAN, 12 (2 \& 3), 3-5.

Nijman, D.J.J. (2004). Differential Effects of Supervisor Support on Transfer of Training, University of Twente, Enschede.

Mathieu, J.E., Tannembaum, S.I., and Salas, E. (1992). "Influences of Individual and Situational Characteristics on Measure of Training Effectiveness", Academy of Management Journal, 35, 828-47.

McGraw, P. (1993). "Back From the Mountain: Outdoor Management Development Programs and How to Ensure the Transfer of Skills to the Workplace", Asia Pacific Journal of Human Resource, 31 (3), 52-61.

Noe, R.A. (1986). "Trainee Attributes and Attitudes: Neglected Influences on Training Effectiveness", Academy of Management Review, 11, 736-49.

Noe, R.A. (2005). Employee Training and Development, Boston, McGraw Hill.

Nunally, J.C., Bernstein, I.H. (1994). Psychometric Theory, McGraw- Hill, New York.

Pfeffer, J. (1998). Seven Practices of Successful Organizations, California Management Review, 40(2), 96-123.

Redding, G., Wong, Y.Y. (1993). "The Psychology of Chinese Organizational Behaviour. In T.D. Weinshall (Eds.)", Societal Culture and Management, 243-270, Walter de Gruyter, Berlin.

Robbins, S.P., DeCenzo, D.A. (2004). Supervision Today, Pearson Prentice Hall, USA.

Rodrígues, C.M., Gregory, S. (2005). "Qualitative Study of Transfer of Training of Student Employees in a Service Industry", Journal of Hospitality ad Tourism Research, 29 (1), 42-66. 
Sekaran, U. (2000). Research Methods for Business: A Skill Building Approach, John Wiley \& Sons, Inc., New York.

Siew Nooi, P. (1988). "Kerajaan Tempatan di Malaysia Pada Masa Kini: Pengalaman dalam Proses Penyusunan Semula", INTAN Buletin, 12 (2 \& 3), 11-33.

Sisson, G.R. (2001). Hands-on-Training: A Simple and Effectiveness Method of on-the-Job Training, Berret-Koehler, San Francisco.

Tai, W.T. (2006). "Effects of Training Framing, General Self-Efficacy and Training Motivation on Trainee's Training Effectiveness", Personal Review, 35 (1), 51-65.

Tracey, J.B., Hinkin, T.R., Tannembaum, S., and Mathieau, J.E. (2001). "The Influence of Individual Characteristics and the Work Environment on Varying Levels of Training Outcomes", Human Resource Development Quarterly, 12 (1), 5-23.

Tsai, W.C., and Tai. (2003). "Perceived Importance as a Mediator of the Relationship between Training Assignment and Training Motivation", Personal Review, 31 (2), 151-163.

Van Maanen, J. (1983). Qualitative Methodology, Sage Publications, Beverly Hills, CA.

Vroom, V.H. (1964). Work and Motivation, John Wiley \& Sons, New York.

Vroom, V.H. (1973). “A New Look at Managerial Decision Making”, Organizational Dynamics, 69-70.

Wood, R., Bandura, A. (1989). "Social Cognitive Theory of Organizational Management", Academy of Management Review, 14, 361-384.

Wong, C., Hui, C., and Law, K.S. (1995). "Causal Relationships between Attitudinal Antecedents to Turnover", Academy of Management Journal, 342-346.

Wright, L.L. (1996). Qualitative International Management Research. In B.J. Punnett, and O. Shenkar (Eds.), Handbook for International Management Research, 63-81, Blackwell Publishers Inc., Oxford, UK.

Xiao, J. (1996), "The Relationship between Organizational Factors and the Transfer of Training in the Electronics Industry in Shenzhen, China", Human Resource Development Quarterly, 7 (1), 55-73.

Yamnill, S., McLean, G.N. (2001). "Theories Supporting Transfer of Training”, Human Resource Development Quarterly, 12, 195-208. 